\title{
Penerapan Model Pembelajaran Project Based Learning (Pjbl) Untuk Meningkatkan Keterampilan Menulis Teks Berita Pada Siswa Kelas VIII SMP Negeri 16 Singkawang
}

\author{
Eti Sunarsih ${ }^{1)}$ \\ Program Studi Pendidikan Bahasa dan Sastra Indonesia STKIP Singkawang \\ e-mail: etisunarsih89gmail.com
}

\begin{abstract}
Abstrak. Penelitian ini bertujuan untuk mengetahui bagaimana penerapan model pembelajaran Project Based Learning dalam meningkatkan menulis teks berita. Penelitian ini dilaksanakan di sekolah SMP Negeri 16 Singkawang. Masalah penelitian ini adalah bagaimana hasil menulis teks berita. keterlaksanaan, peningkatan, aktivitas dan respon siswa dalam menulis teks berita dengan menggunakan model pembelajaran PjBL. Jenis penelitian ini adalah kuantitatif. Bentuk penelitian pre-eksperimental design dengan rancangan one group pre-test post-test design. Populasi penelitian adalah semua siswa kelas VIII dengan jumlah 211. Sampel penelitian diambil dengan menggunakan teknik sampling purposive maka didapat kelas VIII A dengan jumlah 24 orang sebagai kelas eksperimen. Hasil penelitian menunjukkan bahwa hasil pembelajaran menulis teks berita nilai skor post-test 12,63 dan skor pre-test 9,83 dari data tersebut dilakukan perhitungan $\mathrm{N}$-Gain sebesar 0,54 dengan kategori sedang, artinya terdapat peningkatan kemampuan menulis teks berita dengan menggunakan model pembelajaran Project Based Learning. Hasil keterlakasanaan mencapai nilai 94,45 dengan kategori sangat baik. Data rataa-rata aktivitas siswa menunjukkan perilaku negatif sebesar $6,13 \%$ dan perilaku positif sebesar 93,84\%. Data respon siswa menunjukan penggunaan model pembelajaran PjBL menunjukkan respon positif yaitu $88,74 \%$ dan negatif $11,25 \%$.
\end{abstract}

Kata Kunci: Project Based Learning, Menulis Teks Berita

\section{PENDAHULUAN}

Berdasarkan Permen Diknas No.22 tahun 2006 tentang standar isi dijelaskan bahwa ruang lingkup mata pelajaran bahasa dan sastra Indonesia mencakup empat aspek keterampilan berbahasa yang meliputi aspek mendengarkan, berbicara, membaca, dan menulis. Satu di antara keterampilan yang sangat berperan penting dalam pembelajaran Bahasa Indonesia adalah keterampilan menulis. enulis merupakan suatu keterampilan berbahasa yang dipergunakan untuk berkomunikasi secara tidak langsung, tidak secara tatap muka dengan orang lain [5]. Berdasarkan hasil observasi dan wawancara di kelas VIII SMPN Negeri 16 ada beberapa masalah yang dihadapi dalam proses pembelajaran Bahasa Indonesia khususnya pada keterampilan menulis. Pertama, siswa kurang termotivasi dalam poses pembelajaran disebabkan guru hanya melakukan pembelajaran di dalam kelas, sehingga siswa kurang merespon materi yang diajarkan. Padahal, menulis merupakan keterampilan produktif, yang proses pembelajarannya bisa saja dilakukan di luar kelas untuk membantu siswa dalam proses berpikir. Kedua, proses pembelajaran sering terpusat kepada guru, guru tidak melibatkan siswa dalam poses pembelajaran sehingga aktivitas siswa menjadi pasif. Penggunaan model pembelajaran yang tidak tepat dapat mengakibatkan rasa bosan pada siswa dan tentu juga akan berdampak negatif pada hasil belajarnya. Banyak model pembelajaran dan teori belajar yang dibuat oleh para ahli pendidikan untuk meningkatkan hasil belajar. Akan tetapi, tidak semua model dan teori belajar tersebut dapat diterapkan pada setiap pokok bahasan dalam mata pelajaran Bahasa dan Sastra Indonesia. Dalam mengajar guru harus berusaha mengaktifkan siswa, selain itu guru juga harus memperhatikan prinsip-prinsip mengajar yang lain, berdasarkan peaparan diatas maka peneliti akan menerapkan model pembelajaran Project Based Learning. Pembelajaran berbasis proyek diterapkan untuk memotivasi siswa lebih aktif dan berinisiatif untuk memperoleh hal-hal yang mereka inginkan baik pada sisi pengetahuan, pemahaman, dan keterampilannya. Selain itu, pembelajaran berbasis proyek juga mengkondisikan dan memaksa siswa mencari solusi pemecahan masalah dalam menyelesaikan proyeknya. Dengan model pembelajaran seperti ini, siswa akan terbantu dan lebih mudah dalam menulis. Siswa tidak lagi mengalami kesulitan dalam mendaftar hal-hal yang perlu ditulis berdasarkan topik yang dipilih, menentukan gagasan yang akan dikembangkan dalam makalah (berdasarkan pengamatan atau penelitian), menyusun kerangka makalah, dan mengembangkan kerangka menjadi makalah utuh. Dalam pembelajaran berbasis proyek dihasilkan sebuah produk yang hasilnya ditampilkan atau dipresentasikan. 
PjBL adalah sebuah pembelajaran dengan aktivitas jangka panjang yang melibatkan siswa dalam merancang, membuat, dan menampilkan produk untuk mengatasi permasalahan dunia nyata [2]. karateristik penting dari PjBL tersebut fokus pada konsep penting, proses inkuiri, terkait permasalahan nyata, menghasilkan produk, investigasi konstruktif, proyek bersifat realistik dan belajar berpusat pada siswa. Pembelajaran berbasis proyek dilakukan untuk memperdalam pengetahuan dan keterampilan yang diperoleh dengan cara membuat karya atau proyek terkait dengan materi ajar dan kompetensi yang diharapkan yang dimiliki oleh peserta didik. Pembelajaran berbasis proyek ini juga mencakup kegiatan menyelesaikan masalah, pengambilan keputusan, keterampilan melakukan investigasi, dan keterampilan membuat karya. PjBL memungkinkan siswa untuk melakukan aktivitas belajar saintifik berupa kegiatan: a) bertanya, b) melakukan pengamatan, c) melakukan penyelidikan atau percobaan, d) menalar, dan e) menjalin hubungan dengan orang lain dalam upaya memperoleh informasi dan data [2]. Adapun langkah-langkah dalam dalam menerapkan pembelajaran bebasis proyek adalah sebagai berikut, penyajian permasalahan, membuat perencanaan, menyusun penjadwalan, memonitor pembuatan proyek, melakukan penilaian, dan evaluasi [2].

Menulis adalah kegiatan penyampaian pesan (gagasan, perasaan, atau informasi) secara tertulis kepada pihak lain. Menulis adalah sebuah proses, yaitu proses penuangan gagasan atau ide ke dalam bahasa tulis yang dalam praktiknya proses menulis diwujudkan dalam beberapa tahapan yang merupakan satu sitem yang utuh [1]. Suparno dan M. Yunus (2010:15) menjelaskan adapun tahapantahapa proses menulis adalah sebagai berikut. [4]

Tahapan prapenulisan ini merupakan fase persiapan menulis, seperti menentukan topik, mempertimbangkan maksud dan tujuan penulisan, memperhatikan sasaran atau membaca, mengumpulkan informasi pendukung, serta mengorganisasikan ide dan informasi.

Tahap penulisan mengembangkan butir demi butir ide yang terdapat dalam kerangka karangan dengan memanfaatkan bahan atau informasi yang telah dikumpulkan.

Tahap pascapenulisan merupakan tahap penyempurnaan buram yang kita hasilkan. Kegiatannya teerdiri atas penyuntingan dan perbaikan. Kegiatan ini bisa terjadi beberapa kali.

Pada umumnya berita dapat ditulis dengan teknik deskriptif, narasi, dan eksposisi . deskripsi yaitu teknik penulisan berita dengan pola penuturan yang menggambarkan sesuatu yang diberitakannya. Narasi, yaitu teknik penulisan berita dengan pola tutur berdasarkan cerita dariorang lain. Eksposisi, yaitu teknik penulisan berita, yang disertai dengan kiasan-kiasan tertentu dari penulisnya. Sudarman, (2008:92), baik teknik deskripsi, narasi, maupun eksposisi, dalam penulisannya tidak terlepas dari unsur $5 \mathrm{~W}+1 \mathrm{H}$ (What, Who, When, Where, Why, How). [3]. Berdasarkan fenomena di atas, maka penulis akan beranjak dari uraian dan pemikiran tersebut, peneliti mencoba melakukan sebuah penelitian yang berjudul "Penerapan
Model Pembelajaran Project Based Learning (PjBL) untuk Meningkatkan Keterampilan Menulis Teks Berita pada Siswa Kelas VIII SMP Negeri 16 Singkawang .

\section{METODE}

Metode yang digunakan dalam penelitian ini adalah metode eksperimen yang merupakan jenis penelitian kuantitatif. Bentuk penelitian yang digunakan pada penelitian ini adalah pre-experimental design. Rancangan yang digunakan adalah One Group Pre-test Post-test Design. Populasi dalam penelitian ini adalah seluruh siswa kelas VIII SMP Negeri 16 Singkawang tahun ajaran 2015/2016. Populasi dalam penelitian ini berjumlah 211 orang, yang terbagi atas 4 kelas. Sedangkan sampel penelitian ini adalah siswa kelas VIII A SMP Negeri 16 Singkawang berjumlah 24 orang. Teknik pengumpulan data dilakukan dengan teknik pengukuran dengan menggunakan lembar tes berupa LKS, komunikasi tidak langsung dengan menggunakan angket, dan observasi dengan menggunakan lembar observasi.

\section{HASIL DAN PEMBAHASAN}

HASIL

Berdasarkan hasil penelitian maka hasil yang diperoleh adalah sebagai berikut.

Tabel 1 Hasil Menulis Teks Berita

\begin{tabular}{|c|c|c|}
\hline Tes & Rata-Rata & $\begin{array}{c}\text { Standar } \\
\text { Deviasi }\end{array}$ \\
\hline Pretest & 65,56 & 13,85 \\
Posttest & 84,17 & 8,06 \\
\hline
\end{tabular}

Berdasarkan tabel 1 tersebut diungkapkan bahwa nilai rata-rata hasil post-test lebih tinggi dibandingkan dengan nilai pre test. Nilai rata-rata pre-test adalah 65,56 dan nilai rata-rata post-test 84,17 .

Tabel 2 Skor Rata-Rata Kelas Eksperimen

\begin{tabular}{|c|c|c|c|}
\hline Kelas & \multicolumn{3}{|c|}{ Skor Rata-Rata } \\
\hline & Pre Test & $\begin{array}{c}\text { Post } \\
\text { Test }\end{array}$ & N-Gain \\
\hline Eksperiment & 9,83 & 12,63 & 0,54 \\
\hline
\end{tabular}

Dari hasil yang diperoleh skor rata-rata pre-test 9,83 dan rata-rata post-test 12,63 di peroleh rata-rata $\mathrm{N}$-gain 0,54 dengan kriteria sedang. Hal ini menunjukan hipotesis (Ha) diterima, karena terdapat peningkatan kemampuan menulis teks berita dengan menggunakan model pembelajaran PjBL.

Tabel 3 Hasil Observasi Keterlaksanaan Pemebelajarandengan Menggunakan Model PembelajaranPjBL 
Gurral Perdidileon Bahasa dou Sastra Ondonesia

\begin{tabular}{|c|c|c|}
\hline PjBL & Pertemuan 1 & Pertemuan 2 \\
\hline Jumlah skor & 62 & 63 \\
\hline Skor Maksimal & 66 & 66 \\
\hline Rata-Rata & $93,93 \%$ & $95,45 \%$ \\
\hline Hasil Keterlaksanaan & \multicolumn{2}{|c|}{94,69 ( Sangat Baik) } \\
\hline
\end{tabular}

Berdasarakan tabel 3 di atas dapat diketahui bahwa ratarata keterlaksanaan pertemuan pertama dan kedua adalah 94,45 dengan kategori sangat baik. Selain itu ada peningkatan keterlaksanaan dari pertemuan pertama ke pertemuan kedua dengan selisish $1,52 \%$.

Hasil aktivitas siswa dengan kategori pasif sebesar $6,12 \%$ dan aktivitas siswa dengan kategori aktif 93,84. Berdasarkan hasil tersebut aktivitas siswa tergolong kedalam kategori positif.

Berdasarkan hasil perhitungan respon, maka diperoleh hasil dengan respon positif $(\mathrm{SS}+\mathrm{S})$ sebesar $88,74 \%$ dan respon negatif $(\mathrm{KS}+\mathrm{TS})$ sebesar 11,25 . Jika $\mathrm{P}(\mathrm{SS}+\mathrm{S})>$ $\mathrm{P}(\mathrm{KS}+\mathrm{TS})$, maka respon siswa positif, dan sebaliknya, jika $\mathrm{P}(\mathrm{KS}+\mathrm{TS})>\mathrm{P}(\mathrm{SS}+\mathrm{S})$, maka responya negatif. Karena $\mathrm{P}$ $(\mathrm{SS}+\mathrm{S})>\mathrm{P}(\mathrm{KS}+\mathrm{TS})$ maka kesimpulannya respon siswa dalam pembelajaran menulis teks berita dengan menggunakan model pembelajaran Project Based Learning (PjBL) positif.

\section{PEMBAHASAN}

Adapun hasil pengolahan data, diketahui adanya peningkatan menulis teks berita dengang menggunakan model pembelajaran PjBL. Hal ini dapat dilihat dari perhitungan post-test, diperoleh nilai rata-rata 84,17 sedangkan rata-rata pada pre-test rata-ratanya 65,56, hasilnya naik sebesar18,61. Berdasarkan perhitungan tersebut, maka peningkatan hasil belajar menulis teks berita dengan menggunakan model pembelajaran PjBL di SMPN 16 Singkawang diperoleh gain sebesar 0,54 atau dengan kategori sedang.

Berdasarkan hasil pengamatan terhadap keterlaksanaan pembelajaran dengan model pembelajaran $\mathrm{PjBL}$, secara umum peneliti sudah melakanakan serangkaian kegiatan pembelajaran dengan sangat baik. Dari uraian tersebut, pembelajaran dengan menggunakan model pembelajaran kooperatif $\mathrm{PjBL}$ dapat meningkatkan dan membantu siswa lebih aktif dalam kegiatan pembelajaran menulis teks berita. Keterlaksanaan yang dilakukan peneliti pada pertemuan pertama 93,93\% masuk ke dalam kategori sangat baik, dan pertemuan kedua 95,45\% masuk kedalam kategori sangat baik. Rata-rata keterlaksanaan tersebut adalah 94,69\%. Jadi adanya peningkatan keterlaksanaan antara pertemuan pertama dan kedua sebesar $1,52 \%$.

Analisis data tentang aktivitas siswa selama pembelajaran menggunakan model kooperatif PjBL diperoleh berdasarkan perhitungan lembar pengamatan yang dilakukan selama pembelajaran berlangsung. Siswa yang kategori aktif sebesar
93,84\%, sedangkan siswa pasif sebesar 6,13\%. Hal ini menunjukkan selama pembelajaran menulis teks berita dengan menggunakan model pembelajaran PjBL dikategorikan sangat baik.

Setelah proses pembelajaran dilakukan dengan menggunakan model pembelajaran $\mathrm{PjBL}$, siswa diberikan lembar angket respon untuk melihat tanggapan siswa terhadap model pembelajaran yang digunakan yaitu model pembelajaran PjBL. Hasil angket respon siswa diperoleh informasi dengan tanggapan positif dengan kategori sangat setuju (SS) sebesar 45,83\%, setuju (S) sebesar $42,91 \%$ jadi untuk kategori positif $88,74 \%$. Sedangkan untuk tanggapan negatif, kategori kurang setuju sebesar $11,25 \%$ dan kategori tidak setuju $0 \%$, jadi untuk hasil kategori negatif sebesar $11,25 \%$. Jadi, karena kategori pilihan kurang setuju (KS) dan tidak setuju (TS) lebih kecil dibandingkan sangat setuju (SS) dan setuju (S) maka respon siswa dikatakan positif

\section{SIMPULAN DAN SARAN}

\section{SIMPULAN}

Berdasarkan hasil penelitian, maka dapat disimpulkan bahwa model pembelajaran Project Based Learning dapat diterapkan dan mengalami keberhasilan melalui pelaksanaan pre-test dan post-test dalam menulis teks berita pada sekolah SMPN 16 Singkawang. Selain itu, keterlaksanaan penggunaan model PjBL tersebut juga masuk dalam kategori sangat baik, aktivitas dan respon nya juga positif.

SARAN

Diharapkan kepada guru untuk memilih model pembelajaran yang sesuai dengan materi yang diajarkan. Model pembelajaran PjBL sangat cocok digunakan dalam menulis teks berita.

\section{DAFTAR PUSTAKA}

[1] Abidin,Yunus. 2012. Pembelajaran Bahasa Berbasis Pendekatan Karakter. Bandung: Refika Adi Tama.

[2] Sani, Ridwan Abdullah. 2014. Pembelajaran Saintifik untuk Implementasi Kurikulim 2013. Jakarta: PT Bumi Aksara.

[3] Sudarman, Pariyati. 2008. Menulis di Media Massa. Yogyakarta: Pustaka Pelajar.

[4] Suparno dan Mohammad Yunus. 2007. Keterampilan Dasar Menulis Jakarta: Universitas Terbuka.

[5] Tarigan, Hendri Guntur. 2008. Menulis sebagai Suatu Keterampilan Berbahasa. Bandung: Angkasa. 